\title{
Management Decision in Joining Hotel Network on Digital Marketing-Based for Financial and Non-Financial Impacts (Study: 4 and 5-Star Hotels in Yogyakarta Special Region)
}

\author{
Afni Sirait, Sri Luna Murdianingrum \\ Accounting Department, Faculty of Economics and Business, Universitas Pembangunan Nasional Veteran Yogyakarta, Yogyakarta, \\ Indonesia \\ Email: afni.sirait@upnyk.ac.id, sriluna@upnyk.ac.id
}

How to cite this paper: Sirait, A. and Murdianingrum, S.L. (2020) Management Decision in Joining Hotel Network on Digital Marketing-Based for Financial and Non-Financial Impacts (Study: 4 and 5-Star Hotels in Yogyakarta Special Region). Open Journal of Business and Management, 8, 754-762.

https://doi.org/10.4236/ojbm.2020.82045

Received: December 26, 2019

Accepted: March 16, 2020

Published: March 19, 2020

Copyright $\odot 2020$ by author(s) and Scientific Research Publishing Inc. This work is licensed under the Creative Commons Attribution International License (CC BY 4.0).

http://creativecommons.org/licenses/by/4.0/

\begin{abstract}
The purpose of this study outlines the main reasons and factors driving management to join the hotel network on Digital Marketing-based. Besides, this research also wants to formulate the differences that occur before and after joining the hotel networking. This study uses a research design qualitative descriptive that is revealing facts, phenomena, variables, and circumstances that occur when the research is ongoing and presents it as it is. Data collection techniques are interviewing, observing, and studying literature. Furthermore, the data will be processed using descriptive and deductive methods in sequence. The results showed that companies that joined the budget hotel chain were facilitated because they could easily promote their hotel rooms. The facility in the hotel and website digital marketing is depending on the agreement. Today's competition isn't a competition between destinations, so businessmen must be able to take advantage of every opportunity. Each digital marketing has a difference in the distribution of fees or profits on the sale of hotel rooms. However, this study didn't find significant financial and non-financial impacts on 5-star hotel. Contributions from the study provide knowledge to stakeholders about the impact received by conventional hotels that provide access to low-cost hotel aggregators to acquisition hotel rooms.
\end{abstract}

\section{Keywords}

Hotel Budget Chain, Financial, Non-Financial, Improving Process, Profit

\section{Introduction}

The Indonesian government established a new program at the Ministry of Tour- 
ism, "Wonderful Indonesia" to reach the target of 20 million tourists in 2019 (Kemenpar, 2016) [1]. In line with this, Indonesia also has an equivalent program "Pesona Indonesia" which focuses on tourism on all the islands in Indonesia. Java Island is one of the many destinations of domestic and international tourists. Yogyakarta is one of the cities in Java which is a destination for tourists. The growth of the hotel industry is helped by advances in increasingly sophisticated technology. This technological development is utilized by many industries-a start-up based digital marketing that works together with several hotels to offer and market hotel rooms online.

Hotels in Russia that joined the hotel chain for the period 2010 to 2011 and 2012 to 2013 could improve hotel ratings and financial growth also increased (Leite, et al., 2017) [2]. Indications of the development of the hotel chain industry in America turned out to be a long-term commercial problem due to the price-cutting of hotel owner agreements with hotel chains (Pariwisata, 2014) [3]. The phenomenon of technological progress can't be avoided in business processes.

The positive impact of technological advancements helps many aspects of human life to meet daily needs. Information presented about business people in all industry segments can be known through the internet. The internet is becoming one of the tools full of power to advance or destroy a business.

The development of this technology affects the life patterns of customers who can easily move from one choice to another. The platforms that are provided to obtain satisfying needs are also varied and very much. The possibility of the conditions that will be obtained from joining a-based hotel chain digital marketing will be more complex to experience because it involves many parties and the internet as a medium to unite it.

Financial and non-financial can increase significantly, but negative impacts are also likely to occur specifically for hotels that are classified as 5 and 4 .

The background is a basis and reasons for analysis driving factors from management to enter the hotel chain based digital marketing. Besides, it is important to know the impact that occurs in terms of financial and non-financial for the hotel.

\section{Literature Review}

\section{Hotel Chain}

According to McKinsey \& Company (2016) [4] hotel chain is an association of hotel companies that have the same service level and a set of services and work the same approach to living and working under the supervision of their management network. According to Dinas Pariwisata (2014) [3] hotel chains can also be referred to as branded hotel groups that are regulated together in a business rule known as a franchise or run by a single company.

Advantages and Disadvantages of Hotel Network

According to study of Karar (2012) [5] and Krengel (2016) [6] hotel network 
has advantages and weaknesses of the hotel chain are described as follows. First, advantages of hotel networking are:

1) The ability to buy goods and services in large quantities at wholesale prices (discounts);

2) Human Resources. The hotel chain provides centralized training for specialists, which significantly reduces the costs of each chain member separately;

3) Promotion and advertising. National-level advertising campaigns-including newspapers, magazines, radio, and television—are a large part of an independent hotel budget;

4) Centralized ordering system. This allows individual members to combine their business chains;

5) Financing. The chain has an easier time to increase its capital and return it to develop or improve the efficiency of their work;

6) Accounting, market research, construction, and real estate systems are centralized operations. People who work in this area can do it.

\section{Disadvantages of Hotel Chains}

Some disadvantages of hotel chains are as follows (Krengel, 2016) [6]:

1) Standardization leads to a monotonous direction;

2) The absence of a national and authentic touch drives some guests who want something new;

3) The process of introducing new technologies and management methods takes a long time due to the complexity of administrative staff;

4) Hotel chains put pressure on competitors, leading to slower progress in the industry;

5) Lack of individual approach and atmosphere of home comfort;

6) Poor service at one hotel affects the image of the entire brand;

7) Needs additional fees for membership fees.

\section{Digital Marketing}

According to study of Leite, et al. (2017) [2] the behaviour of most hotel visitors is bound by technology. This behaviour is one of the changes that underlie management and marketing strategies in the hospitality industry.

Experian Marketing Service supports the above research which states that in the future managers may be able to think and plan digital-based marketing strategies (Experian Marketing Services, 2015) [7]. Digital marketing disrupts the industry and changes the way businesses find customers. The benefit obtained from digital marketing is to search for data about user behaviour and achievement campaigns in real-time (Kaur, 2017) [8].

Sawicki (2016) [9] defines digital marketing as a form of exploitation of digital technology that is used to form channels that can increase corporate goals more effectively in getting or reaching needs customers'. The following Table 1 contains about the most popular of OTA from some version.

\section{Financial}

Finance is identical to profit margins, return on assets, and cash flow (Anthony, 2011) [10]. Measurement of financial performance uses valuation based 
Table 1. The most popular of OTA.

\begin{tabular}{cccc}
\hline No. & $\begin{array}{c}\text { Digital Marketing Application } \\
\text { Reservation Hotel used Android } \\
\text { \& iOs Version dianisa.com }\end{array}$ & $\begin{array}{c}\text { Website the Best OTA } \\
\text { Version Oryzaonline }\end{array}$ & $\begin{array}{c}\text { Digital Marketing of } \\
\text { OTA booking site in } \\
\text { 2017 Version STAAG }\end{array}$ \\
\hline 1. & Agoda & Traveloka & Traveloka \\
2. & Trivago & Tiket.com & Booking.com \\
3. & Groupon & Agoda \\
4. & TripAdvisor & Pegi-pegi & Expedia \\
5. & Hotels.com & Expedia & Pegi-pegi \\
6. & Expedia Hotels \& Flight & & Tiket.com \\
7. & Traveloka & & Hotelbeds \\
8. & Misteraladin & & Gta \\
9. & Pegipegi & & Hostelworld \\
10. & Raja Kamar & & Staah \\
\hline
\end{tabular}

Resource: Data Process.

on financial information to assess organizational and management performance. Financial oversight emphasizes the role of plan-do-check-act. Financial oversight summarizes the financial results of operations and compares them with planning results.

\section{Non-financial}

The measure of company success is measured from two perspectives, perspectives financial and non-financial. Success Non-financial includes measures of the customer, internal processes, and learning and growth (Blocher, 2014) [11]. Some experts say that currently, factors non-financial are drivers that drive factors financial.

Warren (2011) [12] defined competitive advantages are the highest attraction that companies can give to customers compared to competitors in similar industries. The competitive advantage of a business unit is important to have due to the uncertainty of the competitive environment (Blocher, 2014) [11]. Strategies that can be taken to deal with uncertainty in the business unit environment, namely by innovating products, expanding product lines, and creating excellence from the products/services produced.

Supriyono (2015) [13] defined that the business process is a sequence of work that becomes a unified and mutually sustainable aim to achieve certain objectives of the entity. Business process improvement is done to provide added value to customers so that companies must think about how their business processes are owned. It is hoped that business processes that are in line with the strategy can be to customers and achieve productivity improvements from the goal of improving financially.

\section{Research Methods}

This research uses a descriptive qualitative research design. Qualitative descrip- 
tive is a case study that focuses on research on a particular unit of various phenomena. These characteristics enable research to be carried out in-depth so that the depth of the data will be considered in this research model. The purpose of this study is to uncover facts, phenomena, variables, and conditions that occur when the research is ongoing and present them as they are.

Descriptive qualitative research interprets and tells the data concerned with the situation that is happening, attitudes and views that occur in society, the contradiction of two/more circumstances, the relationship between variables, differences between facts, the influence of a condition, and others (Bungin, 2011 [14].

This research activity includes collecting data, analysis data, interpreting data, and ending with a conclusion that refers to analyze the data. Primary data were obtained from interviews conducted by researchers with the Chairperson of the Indonesian Hotel Association (PHRI) in Yogyakarta, marketing manager, and financial manager.

Data collection techniques carried out using literature study, interviews, and direct observation (Bungin, 2011) [14]. A literature study is conducted to obtain data theoretically by studying various writings related to the issues discussed in this study, such as books, literature, scientific work, previous research, and journals. Interviews were conducted to obtain data conducted directly with respondents. With interviews the data obtained will be more in-depth, being able to explore thoughts or opinions in detail. Direct observations are made with a field visit that is visiting the company that is the object of research. This direct observation provides additional information about the topic under study.

\section{Discussion}

The development of Yogyakarta province as one of the tourism regions is considered to greatly affect the other tourism industries especially after DI Yogyakarta received a platinum award in Indonesia's Attractiveness Award (IAA) in the field of tourism. The results of interviews conducted with the hotel manager stated that this condition has a positive influence on the hotel and increased the number of visitors in DI Yogyakarta. This condition was also helped by the emergence of new tourist destinations in DI Yogyakarta.

\section{Hotel chain based on digital marketing}

The development of hotel chains in Indonesia is increasingly developing by technological developments. The utilization of technology is used to support the promotion of products and services. The following is a list of star hotels in Yogyakarta which are included in-based hotel chains digital marketing.

The digital marketing or online travel agent's most popular (OTA) hotel chains are Traveloka, Agoda, and Tiket.com. Both of these platforms are felt to be the most suitable for user customer in Indonesia. The following Table 2 contains about number of digital marketing platform.

Traveloka provides complete features with some hotels that are almost registered 
Table 2. The number of digital marketing platform.

\begin{tabular}{ccc}
\hline No. & Digital Marketing Platform & The Number of Visitor (million) \\
\hline 1. & Traveloka.com & 15,75 million \\
2. & Tiket.com & 5,56 million \\
3. & Booking.com & 3,97 million \\
4. & Pegi-pegi.com & 2,97 million \\
5. & Agoda.com & 2,40 million \\
\hline
\end{tabular}

Resource: Data Process.

throughout Indonesia with all hotel grades. A variety of payment methods make it easy for customers to pay. Besides, Traveloka provides many travel combinations ranging from picking up customers to other travel combinations. Apart from the side customer, the hotel management is also assisted with several interesting programs that are often offered by Traveloka to hotel management. This offer was felt to be very helpful to provide management interest. So that management will focus on improving quality and service while the marketing side will help.

\section{Advantages of Digital Marketing}

The results of interviews and observations conducted with marketing managers, financial managers, sales marketing, and e-commerce managers mention the advantages of digital marketing or OTA as follows:

1) Help book hotel rooms and other hotel facilities.

2) The visitors are aware of the existence of hotels in several cities.

3) Access can be done anywhere without special terms and conditions.

4) Measuring competence, excellence, and position of each hotel in similar industries.

5) The hotel can map more who will become and is being its main competitor.

6) The payment of hotel rooms can be done with many payment methods making it easier for customers to transact.

7) OTA payments are also made directly to the hotel by the price specified in the contract.

\section{Disadvantages of Digital Marketing}

Besides the advantages described above, there are weaknesses faced by the hotel. These weaknesses such as:

1) Confirmations are often late from the side customer to hotel check-in.

2) The complaints of the customers indicated digitally on the platform review so difficult to muffle the bad news and hoaxes.

3) Difficult to identify the profile of customers who will stay overnight.

4) Sometimes the system often down or delay.

5) The price war that occurred between OTA caused an influence on the image of the hotel that merged.

In addition to the advantages and disadvantages mentioned above, interesting things happen in 5-star hotels. The management feels that digital marketing or 
OTA is only involved because they want to follow current trends and styles. They feel this is not a necessity but a necessity in industry 4.0. This results in them being very selective in choosing digital marketing or OTAs that propose to collaborate with them.

\section{Financial and Nonfinancial Impacts}

In addition to the benefits and weaknesses obtained, the other side that arises from the influence of OTA is financial and non-financial. The results of interviews with hotel management mention the two impacts as follows.

1) OTA or digital marketing affects sales growth for 3 and 4-star (Figure 1) hotels with sales growth of around $10 \%$ - $20 \%$ per year. In contrast to 5 -star hotels that make websites and corporate visitors the main focus. This is due to differences in focus customers targeted by 5-star hotels. 5-star hotels prefer to focus on customers from the segment corporate who will be more loyal.

2) The hotels 3 and 4-star will massively conduct price observations on the platform OTA. Conditions cause the hotel must be able to raise or lower prices at any time because of war openly.

In addition to the financial impacts found non-financial impacts, namely:

1) Frequent carried out training is in the use of technology-based applications and training to improve quality due to OTA requirements.

2) Customers only know them from the digital marketing platform. This resulted in the hotel website itself being left behind and the hotel becoming dependent on sales through OTA.

3) Hotels feel they do not have the bargaining power to determine the price of hotel rooms they have because OTA has the discretion to determine prices based on contractual agreements.

4) The image becomes affected due to discount or promo wars that are often carried out by OTA.

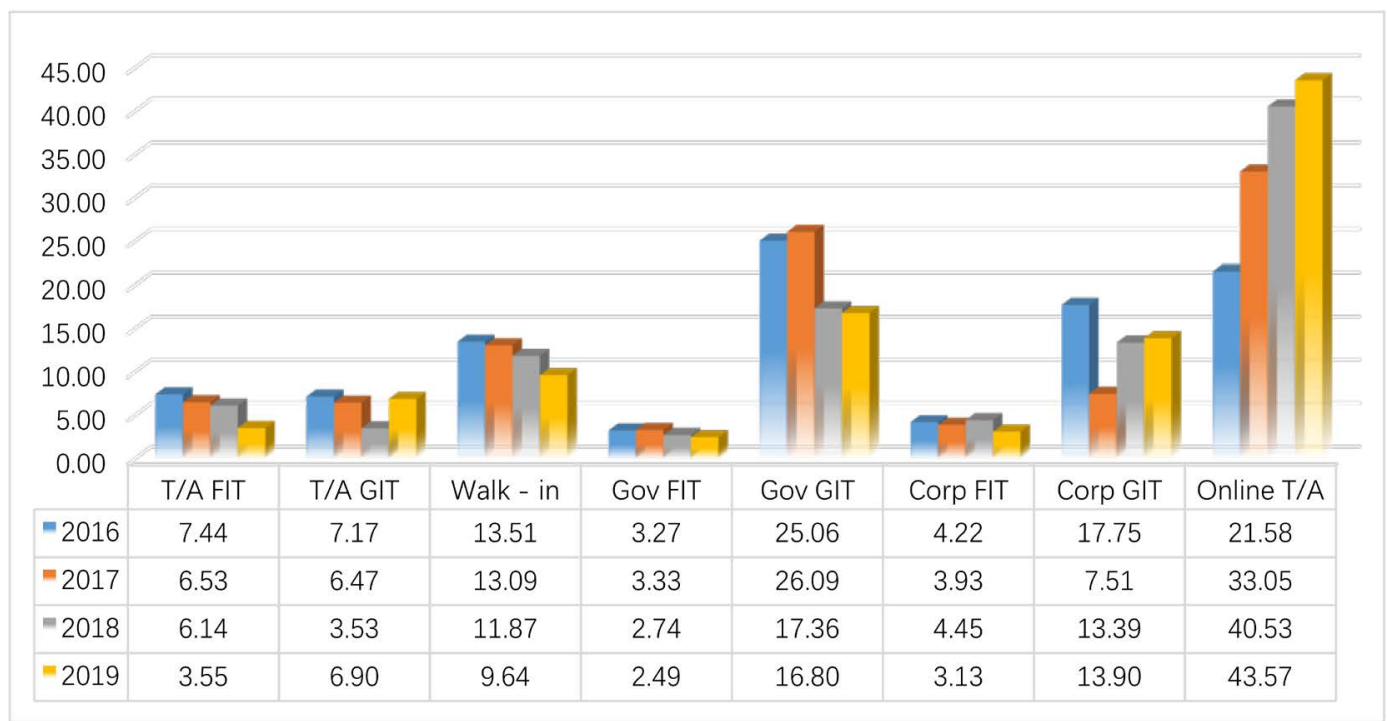

Resources: Data process.

Figure 1. Revenue segmented 2016-2019 hotel 4-stars. 
5) Improving the process that has been done is more to the use of the system used in the OTA process. However, some hotels realize that improving the process is not only for system use but also for employee training. This employee training is carried out because of changes and developments that require it. Employees are trained to meet the expectations of hotel visitors about the conditions and facilities they will get.

\section{Summary of Findings}

Based on the results of the discussions that have been carried out, a summary of the findings is presented as follows.

1) Traveloka digital marketing is the most OTA familiar among visitors from Indonesia.

2) Digital marketing in the form of OTA provides complete features about hotels, various payment methods, can be accessed anywhere and by anyone.

3) Hotel management is difficult to identify potential visitors who book through OTA.

4) OTA systems or networks that are often down or delayed prevent the hotel from checking customer information and data.

5) There is a price war between not only hoteliers but fellow OTAs that market hotel rooms, especially when hotels register more than one OTA. This will also affect image hotels in competing.

6) The impact is financial not felt by 5 -star hotels, because they prefer customers with segments corporate.

7) Online training is often done to employees because of frequent changes in the system of OTA.

8) The hotel website that has been built by the hotel is finally left behind and is not known by visitors.

9) Improving the process is more carried out due to system changes and preserves the image hotel from visitors' expectations of the facilities offered at OTA.

\section{Conclusions}

The conclusions obtained from the results of the discussion above about management's decision to join a-based hotel chain are digital marketing as follows:

1) Digital marketing or OTA helps management to promote market and sell their facilities without having to aim customers directly at theirs.

2) There is a difference in terms of financial and nonfinancial for 3 and 4-star hotels, but not 5 star hotels due to differences in segments market owned.

Based on the conclusions, the researchers provide suggestions for continuous improvement. First, every hotel that joins a-based hotel chain digital marketing or OTA must have bargaining power in determining the price to be published. This is because the competition that occurs is not only experienced by the hotel but also fellow OTAs that exist today. So that competition that is not manifested by OTA has a significant impact on the existence of actual or real hotels. Secondly, every hotel party needs to observe the development of existing OTAs 
with promotions and programs that they always offer so as not to interfere with the sustainability of the hotel in a real way. Third, it is also important for the government to actively fight to oversee the movement of digital marketing platforms or OTAs in the business competition they are conducting, so that competition continues to be conducted in a healthy and avoiding speculation.

\section{Conflicts of Interest}

The authors declare no conflicts of interest regarding the publication of this paper.

\section{References}

[1] Kemenpar (2016) Siaran Per Rakornas Kepariwisataan ke-II Sinergi Pusat dan Daaerah Menuju 12 Juta Wisman dan 260 Juta Wisnus Tahun 2016, diakses pada 1 Juni 2017. http://www.kemenpar.go.id/asp/detail.asp?id=3150

[2] Leite, R.A. and Azevedo, A. (2017) The Role of Digital Marketing: A Perspective from Porto Hotels Managers. International Journal of Marketing, Communication and New Media, No. 2, 88-105.

[3] Pariwisata, D. (2014) Satistik Kepariwisataan 2013. Dinas Pariwisata. Diakses pada 19 Mei 2017.

https://drive.google.com/file/d/1bbw11MJ481KjqGyjweyIK6Vht2AY9uRx/view

[4] McKinsey \& Company (2016) Organization Practice. McKinsey \& Company, New York.

[5] Karar, A. (2012) International Hotel Chains Development. International Law and International Relationship, Diakses pada 2 Juni 2017.

https://www.routledgehandbooks.com/doi/10.4324/9780080914343.ch3

[6] Krengel, L. (2016) The Financial Impact of Joining the Chain and Improving Hotel Rating: A Case Study in Russia. Journal of Business and Management, 4, 659-674. https://doi.org/10.4236/ojbm.2016.44066

[7] Experian Marketing Services (2015) Five Views on How Marketing Will Change in 2015. Diakses tanggal 25 Oktober 2019.

https://www.experian.co.uk/assets/marketing-services/white-papers/wp-digital-insi ghts-5for15.pdf

[8] Kaur, G. (2017) The Importance of Digital Marketing in the Tourism Industry. International Journal of Research-Granthaalayah, 5, 72-77.

[9] Sawicki, A. (2016) Digital Marketing. World Scientific News, 48, 82-88.

[10] Anthony, G. (2011) Sistem Pengendalian Manajemen. Karisma Publishing Group, Tangerang.

[11] Blocher (2014) Manajemen Biaya (Edisi 5). Salemba Empat, Jakarta.

[12] Warren, J.K. (2001) Global Marketing Management. Ebrahimi, A.H., Translated, Publications Office of Cultural Research, Tehran.

[13] Supriyono (2015) Manajemen Biaya (Edisi Pertama). BPFE-Yogyakarta, Yogyakarta.

[14] Bungin, B. (2011) Penelitian Kualitatif. Prenada Media Group, Jakarta. 